\title{
Introduction
}

Over one half of prisoners in the UK have below national average literacy and numeracy skills (Basic Skills Agency 2000; Home Office 2003). The position in USA, Ireland, Canada, Australia and New Zealand is not dissimilar (Morgan and Kett, 2003, Noonan, 2004). It is not uncommon for prisoners with low levels of educational attainment to have had irregular school attendance (Home Office 2001, Dodd and Hunter 1991) for a variety of reasons, such as school refusal, truancy, parental coercion, ill health, suspension and exclusion due to bad behaviour (Carlen et al 1992; Reid, 2005). As a result, half of UK prisoners do not have the skills required by $96 \%$ of jobs and only one out of five can complete an application form (Social Exclusion Unit 2002; Metcalfe et al 2001). The lifestyles and backgrounds of prisoners may also contribute to their disaffection with education, including aspects of social exclusion such as poverty, poor health (including drug and alcohol misuse), living in areas of high unemployment and crime, and familial factors such as living in care, absent parents and parents with low educational attainments. All can impact upon the ability to cope with school and its expectations.

Prisoners also have high levels of learning difficulties such as dyslexia. Loucks (2007) states ' $20-30 \%$ of offenders have learning difficulties or learning disabilities' ( $p 1$ ) and Kirk and Reid (2001) found that 'of the young offenders (50\%) were dyslexic to some degree' (p77). If not addressed these issues can lead to understandable disaffection and result in pupils becoming disruptive or avoiding school altogether. They have also been found to be linked to offending and antisocial behaviour.

This paper discusses the relationship between education and crime as a context for consideration of the purpose and value of providing education for convicted prisoners. The inadequacies of provision in the UK are considered together with the difficulties of ensuring good provision in this environment, before proposing an innovative new approach to educating prisoners - in-cell interactive digital TV (iDTV).

\section{Education and crime}

A relationship between education and crime is well established. Research has demonstrated that lack of engagement with school and low educational attainment is strongly linked to offending and antisocial behaviour, though little is known about those with poor education who do not offend. The nature of this relationship and the question of causality is less well understood because of the many confounding and complex factors implicated in the individual lives of offenders. Maughan et al's (1996) UK study found that 'increased risks of juvenile offending among specifically retarded reading boys seemed associated with poor school attendance, rather than reading difficulties per se' (p405). Williams \& McGee (1994), in a New Zealand study, found that 'antisocial behaviour during the early school years was strongly predictive of delinquency at age 15, particularly for boys, and had a detrimental effect on reading' (p441) and Bennet et al 's (2003) Canadian study concluded 'reading problems may contribute to the early onset of conduct disorder' (p2443) both in and outside school. In contrast Fergusson and Lynskey (1997) in another New Zealand study stated that there is no direct association between reading difficulties and behavioural problems, and argue that other lifestyle and background factors are implicit in this issue. Similarly, Putnins' (1999) Australian study found that there are lower levels of literacy in offender groups but they are not the cause of offending, though they can be an indicator of risk of offending. Putnins suggests that 
low levels of literacy reduce opportunities to desist from crime, which may lead to problems in acquiring basic skills, especially literacy. He says 'literacy makes the point that the relationship between literacy and offending is neither simple nor a universal one' (1999: 158).

The social situations and backgrounds of offenders have been described in a range of research and many variables have been identified as contributory factors to offending behaviour (Nagin and Land, 1993 and Nagin et al, 1995). Most offending is limited to youth, yet 'high-level chronic' offenders continue committing offences into their adulthood (Moffitt 1993). Job instability is a risk factor for continued offending and can be mapped back along a 'trajectory' as resulting from educational disaffection in youth (Nagin et al 1995: 132). Parsons (2002) carried out a longitudinal study of adult offenders in the UK from 1958-1970 revealing that poor numeracy was associated with disruptive and antisocial behaviour, and that truancy and/or exclusion from school was acutely associated with criminal behaviour.

The ramifications for educational disaffection and disrupted learning journeys are wide and far reaching. Lochner and Moretti's (2002) study in the USA found that school actively reduces crime and the cost of crime both social and financial. He argued that school is an effective process and keeping young people in school is cost effective. Sparkes (1999) argues that 'low levels of educational attainment are crucial in generating and sustaining social exclusion' (piii) and Parsons (1999) describes the impact of school exclusions in economic terms, arguing that exclusions from school place strain on other public services. The work of police, social work departments and health professionals are believed to increase significantly for young people who are excluded from school (p99) and thus cost society more.

These arguments relate more to the importance of maintaining pupil engagement in school to prevent them offending rather than to the provision of education for prisoners, though an understanding of their prior experience of education is invaluable in considering such provision. A prison sentence is potentially an opportunity for prisoners to restart their learning journeys. In some instances problems associated with learning are detected and addressed for the very first time in their lives (Talbot 2006). However for many the barriers to learning that posed problems the first time round are resurrected whilst in prison.

\section{Why Educate Prisoners?}

The role of education in prison settings is widely debated, particularly in the USA. Ubah and Robinson (2003) usefully outline two perspectives: the 'optimistic' perspective and the 'pessimistic' reaction. For the first, the 'rehabilitative ideal', they refer to how education can enhance the moral and the social-psychological development of offenders, in turn making 'prisoners feel more human and making prison more bearable by limiting some of its degradations' ( $p 117)$. They cite Hackman (1997) who proposes that,

'Education is an opportunity for an improved lifestyle. An inmate who has been locked up with no opportunity for self-improvement could be released with pent up anger and 'society owes me' attitude. This in turn could start the cycle of crime spinning again. However, through education, those who do not realize they have the capacity to succeed or improve their life with a saleable skill could be released from prison with a positive attitude and become a productive member of society.' (Hackman 1997: 74).

This position is supported by research exploring desistance - the reasons why offenders stop offending. Most offenders stop offending at some point, but the timing and reasons 
vary substantially between individuals (Sampson \& Laub, 1995, Laub and Sampson, 2003, Williamson, 2005). Education can play a key role in this, especially in terms of allowing offenders to write their 'redemptive script' (Maruna, 2001), whereby they can see a positive future for themselves which does not involve offending.

In contrast, the 'pessimistic' view is most frequently illustrated by citing Martinson's (1974) critique of intervention work with offenders. This work aroused considerable and continuing debate about the value of delivering interventions to offenders and challenges whether education can impact on recidivism. However Ubah and Robinson (2003) state that

'the nothing works conclusion distorted and continues to distort the image of the results of offender-rehabilitation efforts in that the nothing-works rhetoric and conclusion are usually the major bases of argument and reference points for critics of offender rehabilitation' ( $p 121)$.

There is also disagreement about the validity of using reconviction or reoffending as the most important measure of the value of education for offenders. On the one hand Duguid et al (1996) argue that the effectiveness of education for offenders needs to be measured against recidivism. Several studies show that educational attainment does reduce offending. For instance Janic's (1998) review of educational achievement and recidivism for prisoners in USA highlights that 'successful releasees have particular characteristics and that correctional education is included among these' ( $p 160$; see also Porporino and Robinson,1992; Beck and Shipley, 1997). Stevens and Ward (1997), Tootoonchi (1993) and Stewart (2005) all found links between educational achievement in prison and reducing re-offending. Sparkes (1999) argues that 'basic literacy and numeracy attainment have a particularly profound effect on labour market participation and unemployment' (p2), and Parsons' (2002) study found a significant relationship between poor levels of literacy and reoffending. On the other hand, Holloway and Moke (1986) state that 'recidivism is a crude measure of program success' (p3), and the UK House of Commons Education and Skills Committee (2005) stated that 'the heavy concentration on basic skills qualifications is based on little more than a hunch', and recommended that more research was needed.

The primary purpose of the provision of education in prison has been as a means of increasing the employability of offenders and thus of reducing reoffending by prisoners on release, what Bayliss calls the 'discourse of literacy for social control' (2003b:162).

Whilst a substantial amount of research has shown that offenders in employment are less likely to offend than those who are unemployed, and there is an established body of research that shows that educational attainment is related to employability, there is a dearth of research that demonstrates that the provision of basic skills education in prison leads to employment of prisoners.

Notwithstanding this academic debate, there is also public concern with regards to the treatment of prisoners. For example Torre \& Fine (2005) describe the mood in the USA where the need for higher education for women prisoners is challenged by public resentment on this matter. There is however, a general view that improved education is a good thing, and the prison service and criminal justice agencies both in the UK and beyond have acknowledged and sought to address the widespread educational deficit of prisoners in both policy and practice. The No Read, No Release programme in USA identifies literacy as a requirement for prisoners in order to achieve release from prison (see Shethar,1993), and in the UK the national strategy for improving adult literacy and numeracy skills (DfES, 2001) identified prisoners as a priority group. 


\section{Provision of prison education in the UK}

Until relatively recently, the provision of education for prisoners in the UK was entirely within the remit of the Prison Service. A unit with specific responsibility for prisoner education, the Prisoner Learning and Skills Unit, was established in 2001, and targets for prisoner education, particularly basic skills education, were introduced in 2002. This was followed by a detailed delivery plan the following year (DfES 2003) that signalled the investment in prison education of £356 million over a three year period 2002-2005/6. In spite of this investment and commitment, more recent reviews of progress about prisoner education have not been good. The House of Commons Select Committee on Education \& Skills (2005) declared 'The current provision of prison education is unacceptable ... in 2004 still less than a third of prisoners had access to prison education at any one time'.

Responsibility for the education of prisoners was transferred to the Offenders' Learning and Skills Service (OLASS) in 2006. OLASS is described as "a means by which existing delivery services are "brigaded together and focussed on to the particular needs of a specific group of learners" (DIUS 2007 p1). The Service was established to address the gaps in offender education and works strategically with the Criminal Justice System and the Department for Innovation, Universities and Skills to a view that improving the basic skills of offenders will enhance life opportunities (i.e. work, education, financial security, civil participation) and assist them to avoid future offending. These are all areas in which prisoners have been shown to have difficulties (Janic 1998). In Ireland, Morgan and Kett's (2003) survey made important recommendations with respect improving adult prisoners' literacy. Barriers to improving literacy are endemic to both prisoners and the setting in which they are placed. They suggest that assessment and referral should be more efficient, that awareness of the benefits of literacy needs to be increased, there is a need to make it more appealing to learn this skill and reach out to disaffected individuals, and also join up provision from inside the prison to that available outside the prison.

The reality of accessing formal education and training whilst in prison is bleak. In 2003 $£ 1,185$ was spent on each prisoner accessing education compared to a secondary school student who costs $£ 2,590$ (Braggins and Talbot 2003) for the same year. The financial commitment to delivering education in prison remains poor. In the USA Pell Grants for education were reduced and eventually withdrawn in 1994 (Karpowitz and Kenner 1995). At any one time only one third of prisoners in the UK can engage in formal educational services (House of Commons Select Committee 2005). The prison regime restricts the time available and educational provision is resource intensive. Overcrowded prisons mean that education and embedded skills courses are often oversubscribed. Movement of prisoners throughout the prison estate is common place. Known as 'churn', prisoners, especially short term prisoners, are moved from prison to prison on a regular basis to meet the needs of the prison estate. This means prisoners are unable to reliably settle in one establishment and the pressures of overcrowding hinder prisoners' ability to gain a sustainable learning experience. Learning can become disrupted and may be repeated over and over again at different prisons (Braggins et al 2003). One reason is that education departments receive only a third of all records of education activity for prisoners after transfers have taken place (Braggins 2002). Prison security and regime are further hurdles for delivery of teaching sessions, with scheduled education sessions often disrupted due to lock-downs and/or prisoners been called to visits or not brought to the educational facilities by prison officers as a result of staff shortages. These are some of the reasons that few prisoners are able to achieve a qualification during their time in prison: Home Office information in 2001 states that only one out of five prisoners achieve 
academic qualifications. Noonan (2004) identifies the same issues and barriers to learning in Australian prisons

Many prisoners choose not to engage in formal educational services for a variety of reasons. Some opt to work because in many institutions prisoners can earn more for work than going to education classes. Other prisoners may choose to avoid education because of bad relationships with education and learning in the past, e.g. not achieving at school, learning difficulties or being bullied, factors that can impact on an individual's motivation to engage and succeed at learning (Worrall 2003, Ruess 1999, Home Office 2000). Learning is also labelled negatively by some prisoners and as a consequence may discourage people from engaging with learning provisions in prisons (Morgan and Kett 2003).

'the limited curricula that education departments are able to offer serves to turn prisoners away from education' (Hughes 2004).

Adaptation to prison, according to Clemmer (1958), means that prisoners cope with prison life in a number of ways and develop prison personas in an attempt to survive their incarceration. For some prisoners learning is part of their prison identity (gleaners) and for some it can be rejected (deviants). For them, learning is not considered to sit comfortably with the public 'prisoner' identity (Goffman,1961). For example male prisoners may not consider learning to be 'masculine'. For others it is not considered an adult activity and showing you are open to change and self-improvement can be considered to be a risk and demonstration of vulnerability. These tensions are complex and not limited to the prison setting (see Willis, 1977).

There are also questions about the quality of education provision in prisons. In the UK education provision is contracted out to external education providers such as further education institutions and nationally there are up to 28 different providers (Taylor 2005 and OLASS, 2004). Many teaching staff are sessional and part time. They are unable to access resources on site to make suitable preparation (Taylor, 2005), and staff turnover is high. Bayliss (2003a) documents neglect of some learners as a product of the short comings in provision. Support for prisoners with learning difficulties and disabilities is also limited due to resources, including time and teaching staff abilities to carry out diagnostic tests (Talbot 2006).

Teaching and learning in UK prisons is subject to inspection by the Office for Standards in Education (Ofsted) and the Adult Learning Inspectorate (ALI). These inspections use essentially the same framework applied to schools and colleges and have been criticised for not taking the prison context into account, including regime, resources, overcrowding, security and the high levels of learners with difficulties (Taylor 2006). Prison establishments find it difficult to respond to the recommendations outlined in such reports because they are not typical teaching and learning sites like schools or colleges. Prisons in the UK have limited access to IT facilities for prisoners, particularly access to the internet (Taylor 2005), contrary to what is occurring elsewhere in the teaching and learning sector. The digitisation of learning has escalated since the beginning of the millennium, yet prison settings have been unable to respond in the same ways due partly to allocation of funds, but more significantly to security and the need to control prisoners' access to the outside world via such networks. Teachers do acknowledge the limitations of teaching practice in prisons such as using new technologies and the ability share information across different prison sites, all of which can contribute to success in these settings (Irwin 2008). As a result, feedback from such inspections do little to boost the morale of the existing staff as they are subject to public scrutiny (Taylor, 2005). 
The nature of prison education in the UK is further called into question by a recent government report on prison education in England \& Wales which recommends:

"The prison education system is focused on the requirement of the institution to meet Key Performance Targets rather than on the needs of the prisoner.... Any new system needs to ensure that prisoners themselves take ownership of their education." (House of Commons 2005: 27)

This is hard to achieve within the currently available provision. In UK and Ireland shifts in policy and consequently practice have appeared, yet because each prison has autonomy to determine their own education policy changes appear in pockets across the sector. For instance HMP Leeds, UK screens all prisoners for dyslexia on admission and embeds basic skills learning in non-traditional subjects to attract learners (SEU 2002), yet this is not uniform practice elsewhere in the sector. Each prison establishment prioritises education differently and there is no uniformity or standard curriculum across the sector. More recently some prisons have sought to match prisoners' pay to the highest paid jobs elsewhere in the prison establishment, removing one disincentive to education, and opportunities for part-time education are becoming viable in some prisons. There are also examples of using the 'untapped resources' (Devilly et al 2003) of prisoners as 'tutors' and 'mentors'. The Toe-by-Toe peer learning initiative is now available in every prison establishment in England and Wales, where prisoners teach other prisoners to read and write. The Social Exclusion Unit (SEU 2002) also report that 'prisoners act as peer tutors and undertake the City and Guilds Initial Certificate in Teaching Basic Skills' (p46).

\section{In-cell: a time and place for learning}

Learning in prison occurs during structured times in the course of a prison regime, usually timetabled periods during the day and is modelled on formal school practice. Sessions tend to take place in classrooms, gyms and workshops. In some instances prisoners have 'homework' which they can take back to their cells and complete for subsequent sessions. Prison libraries in the UK are now common place, yet attendance and use of the facility is down to prisoner choice and time to be able to get to it. Given the structured regime in prison these opportunities are limited. The recent House of Commons report (2005) argued that prison education should become 'learner-centred' and considered within the wider needs of prisoners. But such a learner-centred approach to education is difficult within the current prison environment. As discussed previously, the demands of the prison regime combined with the aversion to formal education of many prisoners limit the number of prisoners who engage in the courses offered by prison education units. The learning needs of prisoners are often complex, with high levels of learning disability and special educational need. Assessment procedures are unsophisticated and inadequate with education units having little capacity to respond to such needs when identified. Limited resources and security concerns restrict the education that can be provided by other means such as on-line e-learning via the internet or individual tuition. There are some successful initiatives, such as the 'Toeby-toe' scheme, but they reach relatively low numbers of prisoners.

Little is known about self-directed and informal learning in the prison setting, yet it undoubtedly takes place. In the UK, US and many other places a prisoner spends around 18 hours a day locked behind their cell doors. In the limited time outside their cells prisoners attend work, education, use the telephone, have visits, take a shower, make applications and attend to matters relating to health (Knight 2005b). Recent research has also revealed that even when cell doors are unlocked some prisoners are 
choosing to remain behind their doors in attempts to avoid conflict, maintain privacy and to keep themselves safe (Knight, 2009; Jewkes 2002).

Time inside a prisoner's cell is the most private space a prisoner manages to achieve, despite frequently having to share a cell with another person. Periods locked in cells or 'banged up' are considered free and unstructured time and the prisoner is at liberty to choose what to do, but as Ubah and Robinson warn (2003), 'without correctional education inmates are left to their own, limited resources and all-defeating imagination' (p118). In UK access to in-cell TV and radios is now common place and a popular activity (Knight 2009), other activities include reading and writing, playing games, sleeping, eating and talking to their cell mate. Time locked up is a vulnerable time for prisoners: feelings of boredom, isolation and depression are common place and can escalate into harm or violence either against themselves or others (Liebling et al 1999). The fear of self deterioration is well documented in prisonisation literature and prisoners reveal how they attempt to preserve themselves during containment. Knight (2009) has recently found that prisoners use in-cell TV as an antidote for mental deterioration, choosing to watch documentaries, quizzes, and wildlife programmes, for mental stimulation to avoid turning into a 'cabbage' or brain dead (see also Jewkes, 2002) and Knight, 2009). A prisoner's cell is thus a good space for learning (Hughes 2004).

In the UK the Prison Service is under pressure to make prison meaningful and contribute towards reducing re-offending. Given large budget constraints and few resources the provision of meaningful activities for prisoners is restricted to the small amounts of time they are allowed outside their cells. A key performance target is 'purposeful activity' but achieving desired levels of this is difficult. One way to increase this activity would be to make purposeful activity achievable inside prisoner's cell, but this is problematic and there is no way to measure or monitor such activity. There is also the danger that the public and policy makers would see such provision as a luxury. The presence of TV in prisoners' cells in the UK has been met with resistance and still sits uncomfortably with policy makers (Knight 2005a, Jewkes 2002).

One possible solution to this problem is t-learning: a term that has been coined to mean TV-based interactive learning (Pazos-Arias et al 2008). It does have limitations, especially when compared with e-learning (learning using computers and the internet), but importantly it has two key advantages that are particularly valuable in the context of prisoner learning:

1. It uses a technology with which most people are familiar: the digital television and its remote control. The move over to digital services is now well advanced in the UK, with a wide range of digital television services obtainable. These are available free upon the purchase of a set top receiver or TV with a built in receiver, or by subscription to satellite or cable providers. These services have a limited interactivity available to extend the range of content available to the viewer. Analogue services are being phased out, with a full switchover to digital services scheduled for 2012. The remote control is a standard accessory with both analogue and digital TVs, so most people are very familiar with its use. Mobile phones use a similar handset and the widespread use of texting means that most people are familiar with the potential extra functionality of the remote control. Within a prison setting with limited resources to train people in the use of new technology this is a distinct advantage as prisoners will be able to adapt to new uses relatively easily and with limited support.

2. The wiring required for interactive TV services is very secure and containable within a prison environment. The signal with the outside world is one way only - inwards meaning that there is no possibility of prisoners communicating with people outside the prison by this means. Interactive content made available through the TV can be 
contained and maintained on an internal server. A television set is a standard piece of equipment in most prison cells. To meet the new requirements of digitalisation these are increasingly digital enabled TVs, with some prisons providing prisoners with access to a limited range of digital television channels. It is thus relatively easy and secure within the existing infrastructure to make interactive learning options available to prisoners in their cells using interactive digital television (iDTV).

The provision of access to in-cell t-learning facilities has the potential to address many of the learning issues of prisoners. Well designed content will encourage prisoners to engage with the system and thus with learning. The privacy afforded by their cells avoids the public admission that they are engaging in education or that they need education. The system is completely contained within the prison and thus there are no security issues. Support materials can be developed within the existing resources of the prison, and no additional staffing is needed.

IDTV has been successfully trialled with offenders in the community and has been shown to successfully engage people with poor literacy and numeracy who have poor experiences of traditional education (Taylor et al, 2006). The content developed for this system included literacy and numeracy, financial literacy, job seeking skills, coping with family responsibilities, and health, drugs and alcohol awareness and help, and its potential for use in prisons has been explored (Attewell et al 2007). Research into the educational intention of prisoners (Manger et al 2006), shows a range of reasons for engaging with education. One important reason is to provide some variety in the routine of prison and a connection with the outside world (Knight, 2005b), which suggests that many prisoners would be tempted to try such a system if available. It also provides respite from the routine.

There are potential additional benefits for the prison too. In common with most publicly funded agencies in the UK, the prison service is target-driven. Some of those targets relate specifically to education, but a key target relates to 'purposeful' or 'constructive activity'. This is a way of identifying the rehabilitative aspects of a prison sentence, and as well as engagement with education classes includes time spent in work and in formal programmes designed to reduce offending. Meeting these targets is becoming increasingly difficult because of overcrowding in prisons and lack of staff to manage prisoners when they are out of their cells. This has resulted in more time spent in cells and what is normally non constructive activity. If prisoners were engaged in education during this time this could contribute to the prison's 'constructive activity' targets. Monitoring use of the system could be built into the system. At the same time prisoners who are constructively engaged tend to be easier to manage and cause less of a problem to staff, making the job of those staff that are available easier. This can lead to an improvement in prisoner-staff relations.

\section{Conclusion}

Very high proportions of prisoners have substantial educational needs. This limits the ability of these individuals to (a) make a positive contribution to society because of the increasingly limited employment opportunities for unskilled and illiterate workers; and (b) benefit form the increasingly available rehabilitative programmes being introduced in prisons, as limited literacy means limited comprehension and communication - skills that are necessary to fully participate in the programmes. Strategically this makes it harder to meet prison and national targets to engage prisoners in constructive activity and to reduce offending. In the UK there is a recent awareness of the significance of the prison population as a means of achieving national targets for literacy, with the education of prisoners being a key component of the government's Skills for Life programme, which 
aims to improve the basic skills of the population generally: 'The Prison Service is a major contributor to the national target.' (DfES 2003 p5).

Research has highlighted many of the barriers to education that confront prisoners but also their motivations and willingness to engage in the right sort of education. We very much take Ubah \& Robinson's optimistic view that the provision of education for prisoners will make a positive contribution to the lives of these individuals and to society more generally and believe that in-cell iDTV can make that more achievable. 


\section{References}

Attewell, J, Taylor, P., Savill-Smith, C (2007) Interactive digital television for offender e-learning - exploring the potential, London, Learning and Skills Network 21

Bayliss, P. (2003a) Sentenced to a term of education in Adults Learning 14(10) p18-

Bayliss, P. (2003b) Learning behind bars: time to liberate prison education in Studies in the Education of Adults 35(2) p157-172

Beck, A.J. and Shipley, B.E. (1997) Bureau of Justice Statistics Special Report: Recidivism of Prisoners released in 1983 in US Department for Justice

Bennett Kathryn J Brown K. S; Boyle M; Racine Y; Offord Dan (2003). Does low reading achievement at school entry cause conduct problems? Social science \& medicine 56(12): 2443-2448

Braggins (2002) Shared Responsibilities: Education for Prisoners at a Time of Change NATFHE

Braggins, J. And Talbot, J. (2003) Wings of Learning: the role of prison officer in supporting prisoner education London, The Centre for Crime and Justice Studies

Carlen, P., Gleeson, D. And Wardhaugh, J. (1992) Truancy: the politics of compulsory schooling Milton Keynes: Open University Press

Clemmer, D. (1958) The Prison Community New York Rinehart

Devilly, G.J., Sorbello, L., Eccleston, L. And Ward, T. (2005) Prison-based pereducation schemes in Aggression and Violent Behavior 10 pp219-240

Department for Education and Skills (DfES) (2003). Improving Offenders' Learning and Skills: Delivery Plan 2003/4-2005/6. London: DfES.

Department for Employment and Education (2001). Skills for Life: the National Strategy for Improving Literacy and Numeracy Skills. Nottingham: DfEE.

Department for Innovation, Universities \& Skills (2007). The Offenders' Learning and Skills Service (OLASS) in England: A Brief Guide. London: Department for Innovation, Universities \& Skills

Dodd, T. and Hunter, P. (1991) The National Prison Survey London, Stationery Office

Duguid, S., Hawkey, C. And Pawson, R. (1996) Using recidivism to evaluate effectiveness in prison education programs in Journal of Correctional education Vol. 47:2 pp74-85

Fergusson, D.M and Lynskey, M.T (1997) Early Reading Difficulties and Later Conduct Problems in Journal of Child Psychology and Psychiatry 38:8 pp899-907

Giles, M., Tram Le, A., Allan,M., Lees,C., Larsen, A.C. and Bennett, L. (2007)The role of education and training in prison to work transitions in Dawe, S. (2007) (ed) Vocational education and training for adult prisoners and offenders in Australia: Research readings National Centre for Vocational Education Research (NCVER)

Goffman, E. (1961) Asylums: Essays on the Social Situation of Mental Patients and Other Inmates London: Penguin

Hackman, K.M (1997) Correctional education- Challenges and changes in Journal of Correctional Education 48 pp74-78 
Holloway, J. And Moke, P. (1986) Post-Secondary Correctional Education: An Evaluation of parolee performance Wilmington College

Home Office (2001) Through the Prison Gate: a joint thematic review by HM Inspectorates of Prisons and Probation, London, Stationery Office

Home Office (2003) The resettlement of short-term prisoners: an evaluation of seven Pathfinders London, RDS Occasional Paper No 83

House of Commons Education and Skills Committee (2005). Prison Education: Seventh Report of Session 2004-05, Volume I Report, together with formal minutes. London: House of Commons.

House of Commons Public Accounts Committee (2009). Skills for Life: Progress in Improving Adult Literacy and Numeracy. Third Report of Session 2008-09. London: the Stationery Office

Hughes, E (2004) Free to Learn? Mitcham, Prisoners' Education Trust

Irwin, T. (2008) The 'Inside' Story: Practitioner Perspectives on Teaching in Prison in The Howard Journal Vol. 47:5 pp512-528

Janic. M. (1998) Does Correctional Education Have an Effect on Recidivism? In Journal of Correctional Education Vol. 49: 4 pp152-161

Jewkes, Y (2002) Captive Audience: Media, masculinity and power in prison Collumpton, Willan

Karpowitz, D and Kenner, M (1995). Bard Prison Initiative: Education as Crime Prevention - The Case for Reinstating Pell Grant Eligibility for the Incarcerated.

Kirk, J. And Reid, G. (2001) An Examination of the Relationship between Dyslexia and Offending in Young People and the Implications for the Training System in Dyslexia 7 pp77-84

Knight, V (2005a) The Potency of In-Cell Television- The Appropriateness and Usefulness Prison Service Journal No. 161 November 2005

Knight, V (2005b) An Investigation into Mass Communication Consumption in a Closed Young Offenders' Institution Participations Journal Vol. 2 Issue 1 www.participations.org

Knight, V (2005c) Remote Control: The role of TV in prison Criminal Justice Matters No. 59 London: The Centre for Crime and Justice Studies

Knight, V. (2009) The role of in-cell television for adult male prisoners: a dangerous space? Unpublished research findings, De Montfort University, Leicester, UK, vknight@dmu.ac.uk

Laub, J H and Sampson, R J (2003). Shared Beginnings, Divergent Lives: Delinquent Boys to Age 70. Cambridge Mass: Harvard University Press

Liebling, A., Muir, G., Rose, G. and Bottoms, A. (1999) Incentives And Earned Privileges For Prisoners -An Evaluation Research Findings No. 87, London, Home Office http://www.homeoffice.gov.uk/rds/pdfs/r87.pdf accessed 05/08/08

Lochner, L. and Moretti, E. (2002) The Effect of Education on Crime: Evidence from Prison Inmates, Arrests, and Self-Reports California Center for Population Research University of California, LA

Loucks, N. (2007) The prevalence and associated needs of offenders with learning difficulties and learning disabilities No One Knows. London, Prison Reform Trust 
Manger, T., Eikeland, O.-J., Asbjornsen, A., \& Langelid, T. (2006). Educational intentions among prison inmates. European Journal on Criminal Policy and Research, 12, 35-48.

Martinson, R. (1974) What works? - Questions and answers about prison reform in The Public Interest, 35(2), 22-54.

Maruna, S (2001). Making Good: How Ex-Convicts Reform and Rebuild their Lives. Washington: American Psychological Association.

Maughhan, B., Pickles, A., Hagell, A., Rutter, M., Yule, W. (1996) Reading Problems and antisocial behaviour: developmental trends in comorbidity in Journal of Child Psychology and Psychiatry 37:4 pp405-18

Metcalf, H., Anderson, T. \& Rolfe, H. (2001) Barriers to employment for offenders and ex-offenders, Research Report, No. 155, Department for Work and Pensions, London

Moffitt, T.E. (1993) 'Adolescence-limited and life-coursepersistent antisocial behaviour: A developmental taxonomy' in Development and Psychopathology 5 p135-151

Morgan, M. and Kett, M. (2003) The Prison Adult Literacy Survey: Results and Implications Dublin, Irish Prison Service

Nagin, D.S., Land, K.C. (1993) Age, criminal careers, and population heterogeneity: Specification and estimation of a nonparametric, mixed Possin model in Criminology 31 pp327-362

Nagin, D.S., Farrington, D.P and Moffitt, T.E (1995) Life-course trajectories of different types of offenders in Criminology Vol. 33 No. 1 pp111-139

Noonan, P., (2004) Equity in education and training in correctional services institutions in Bowman, $\mathrm{K}$. Equity in vocational education and training, Adelaide: NCVER

Parsons, C (1999). Education, Exclusion and Citizenship. London: Routledge.

Parsons, S (2002) Basic Skills and Crime London, Basic Skills Agency

Pazos-Arias, J J, López-Nores, M, García-Duque, J, Díaz-Redondo, R P, BlancoFernández, Y, Ramos-Cabrer, M, Gil-Solla, A, and Fernández-Vilas, A (2008). Provision of distance learning services over Interactive Digital TV with MHP. Computers \& Education 50 (2008) 927-949

Porporino, F.J. and Robinson, D. (1992) The Correctional Benefits of Education: A Follow-Up of Canadian Federal Offenders Participating in ABE in Journal of Correctional Education Vol. 43:2

Putnins A. L. (1999) Literacy, numeracy and non-verbal reasoning skills of South Australian young offenders in Australian Journal of Education Vol. 43:2 pp157-171

Reid, K. (2005) The causes, views and traits of school absenteeism and truancy: an analytical review in Research in Education No.74 pp59-82

Ruess, A. (1999) Prison(er) Education in The Howard Journal 38(2) pp113-127

Sampson, R J and \& Laub, J H (1995). Crime in the Making: Pathways and Turning Points through Life. Cambridge Mass: Harvard University Press

Shethar, A (1993). Literacy and Empowerment? A Case Study of Literacy Behind Bars in Anthropology and Education Quarterly pp357-372.

Social Exclusion Unit (2002) Reducing re-offending by ex-prisoners London, Office of the Deputy Prime Minister, UK 
Sparkes (1999) Schools, Education and Social Exclusion Centre for Analysis of Social Exclusion, London School of Economics, London

Stevens, D.J. and Ward, C.S (1997) College Education and Recidivism: Educating Criminals is Meritorious in Journal of Correctional Education 48:3 pp106-111

Stewart, D (2005) An evaluation of basic skills training for prisoners Home Office Findings No. 260, London, Home Office

Talbot, J. (2006) No One Knows: Identifying and supporting prisoners with learning difficulties and learning disabilities : the views of prison staff London, Prison Reform Trust

Taylor, P., Traxler, J. \& Attewell, J. (2006) Interactive digital TV for learning; the Kickstart TV pilot project London, Learning and Skills Network

Taylor, S (2002) Widening the Net in Prison Service Journal_No 142, July 2002, Leyhill, HM Prison Service

Taylor, S. (2005) Internet Inside London, Forum for Prisoner Education

Tootoonchi, A. (1993) College Education in Prisons: The Inmates Perspectives in Federal Probation 57:4 pp34-40

Torre, M.E and Fine, M. (2005) Bar None: Extending Affirmative Action to Higher Education in Prison in Journal of Social Issues Vol. 61:3 pp569-594

Ubah, C.B.A . and Robinson, R.L. (2003) A Grounded Look at the Debate Over Prison Based Education: Optimistic Theory versus Pessimistic Worldview in The Prison Journal Vol. 83:2 pp115-129

Williams, S. and McGee, R. (1994) Reading attainment and juvenile delinquency in Journal of Child Psychology and Psychiatry 35:3 pp441-59

Williamson, H (2005). Milltown Boys Revisited. Oxford: Berg Publications.

Willis, P (1977) Learning to Labour: how working class kids get working class jobs Farnborough: Saxon House

Worrall, A. (2003) Overcoming Barriers to Learning: Educating Young Men in Prison. Birmingham, University of Central England 